University of South Florida

DIGITAL COMMONS

Digital Commons @ University of

@ UNIVERSITY OF SOUTH FLORIDA

South Florida

USF St. Petersburg campus Faculty

Publications

USF Faculty Publications

2017

\title{
A sustainability index for small island developing states.
}

Philip van Beynen

Fenda A. Akiwumi

Kaya van Beynen

University of South Florida St. Petersburg, kayatown@usf.edu

Follow this and additional works at: https://digitalcommons.usf.edu/fac_publications

Part of the Environmental Sciences Commons

\section{Recommended Citation}

van Beynen, P., Akiwumi, F.A. \& van Beynen, K. (2017). A sustainability index for small island developing states. International Journal of Sustainable Development \& World Ecology. doi: 10.1080/

13504509.2017.1317673

This Article is brought to you for free and open access by the USF Faculty Publications at Digital Commons @ University of South Florida. It has been accepted for inclusion in USF St. Petersburg campus Faculty Publications by an authorized administrator of Digital Commons @ University of South Florida. For more information, please contact digitalcommons@usf.edu. 
This is an Accepted Manuscript of an article published by Taylor \& Francis in International Journal of Sustainable Development \& World Ecology on 16 April 2017, available online: http://www.tandfonline.com/10.1080/13504509.2017.1317673. 
A Sustainability Index for Small Island Developing States.

Philip van Beynen ${ }^{1}$, Fenda A. Akiwumi ${ }^{1}$ and Kaya van Beynen ${ }^{2}$

vanbeyne@usf.edu, akiwumi@usf.edu, kayatown@usfsp.edu

${ }^{1}$ School of Geosciences, University of South Florida, Tampa, FL 33620

${ }^{2}$ Nelson Poynter Memorial Library, University of South Florida St. Petersburg

\begin{abstract}
This paper proposes a novel approach to measuring the progress of Small Island Developing States (SIDS) towards sustainable development (SD) as set by the UN Sustainable Development Goals 2030. Currently, these goals do not provide adequate guidance on how countries might measure their progress towards sustainability. We use these goals and a subset of their targets to develop an index with concrete targets, through the use of pertinent sustainability indicators, that SIDS should aim to achieve a sustainable society. In addition to the three categorical pillars of sustainable development (social, economic, and environmental), we included the category Climate Change and Disaster Management (incorporating Disaster Risk Reduction). The basis of our decision is that the UN and the Intergovernmental Panel on Climate Change have both recognized the vulnerability of SIDS to both environmental hazards. Our index scores a total 70 individual indicators for the four categories to track the progress of a SIDS towards a sustainable society. Using the Caribbean nation, Republic of Trinidad and Tobago, as our SIDS case study, we report the average of the scores for each category to illustrate its progress towards sustainability. Overall Trinidad and Tobago is slowly progressing towards a more sustainably developed society. Our results show that the nation is only moderately successful regarding progress in three traditional pillars of SD, social, economic and environmental. However, Trinidad and Tobago scores poorly in the Climate Change and Disaster Management category and needs to improve in this area especially due to its vulnerability.
\end{abstract}

Keywords: small island developing states; sustainable development, index, Trinidad \& Tobago, climate change 


\section{Introduction}

Small island developing states (SIDS), frequently characterized by coastal communities, stagnant populations, and limited resources, are highly vulnerable to economic, social and environmental volatility and impending risks from natural disasters and climate change (Briguglio 1995; Pelling and Uitto 2001; Byrne and Inniss 2002; Turvey 2007; Kelman 2014). Faced with these threats, many SIDS nations have realized the importance of and need for sustainable development (SD) agendas (Ghina 2003). In 1992 the Rio de Janeiro United Nations Conference on Environment and Development (UNCED) called for development of sustainability indicators under the broad categories of social, economic, and environment that could help steer SD. The United Nations (UN) considers indicators essential "to provide solid bases for decision-making at all levels and to contribute to self-regulating sustainability of integrated environmental and development systems" (UN 1992). While recognizing the inevitability and necessity of development, the 2002 UN World Summit on Sustainable Development (WSSD) in Johannesburg, South Africa stated that future access to our natural resources can only be assured if this development occurred within a sustainable framework. Building on this, the 2005 World Summit in New York City agreed that SD should incorporate three components - economic development, social development, and environmental protection (UN 2005). The 2012 UN Sustainable Development Agenda enacted at the Rio+20 Conference on Sustainable Development, identified 17 Sustainable Development Goals with 169 targets and a deadline of 2030 for their achievement. These UN sustainable development goals focus on issues such as gender equality, poverty alleviation, environmental resource sustainability, civic society action/participation, and social, economic, educational, and environmental equity and justice (UN 2015, 2016a).

A keystone of the aforementioned Agenda is improving the lives of women, particularly in developing nations (UN 2016a). In these nations, women's ability to be a major contributor to household income is restricted yet "greater gender equality also enhances economic efficiency and improves other development outcomes" (Revenga and Shetty 2102). As such, women's social and economic advancement is a critical component of SD (Braidotti 1994; Kabeer 2005; Sachs 2012; Unterhalter 2005). This advancement also plays a critical role is the alleviation of poverty promoting sustainable livelihoods (Krantz 2001). Consequently, we recognize the important role women play in SD by integrating associated indicators in the first three categories of the index.

A specific focus on SIDS emerged at the 1992 UNCED in Rio de Janiero. Their vulnerability to human induced environmental threats as particularly noted (Kelman 2006; IPCC 2007) and Chapter 17 of Agenda 21 highlighted the risks posed by climate change, sea level rise, and other related hazards. Two years later the UN Global Conference on Sustainable Development of SIDS outlined 14 priority areas for action called the Barbados Plan of Action (BPoA). The World Summit on Sustainable Development in 2002 in Johannesburg, South Africa requested a review of the BPoA and created a set of action plans for promoting sustainable development for SIDS. The Mauritius Strategy for Further Implementation of the Programme of Action for Small Island Developing States (MSI) of 2005 marked the 10 year review of the $\mathrm{BPoA}$. It stated that additional strategies and actions were required to help implement the BPoA. In 2012, at the Rio +20 conference in Rio de Janeiro, once again, the UN highlighted SIDS as entities of special concern and called for a third international conference on SIDS in 2014 to review the BPoA and the MSI. This call resulted in the 2014 Third International Conference on 
Small Island Developing States in Apia, Samoa, named the Samoa Pathway (Island Voices, Global Choices 2014). At this conference the member states reaffirmed their commitment to the continuing efforts to implement the BPoA and MSI and the need to focus on the risks posed by climate change while recognizing that economic challenges had slowed their progress (Island Voices, Global Choices 2014).

The central aim of this study was to create a standardized means of measuring and evaluating the progress of SIDS towards SD. Several types of indexes were considered. One method of measuring quantitatively the SD of a developing nation is a Composite Vulnerability and Resilience (VR) Index (Angeon and Bates (2015). This approach concentrates on mathematical algorithms to the success of a nation's SD policies with a heavy emphasis on economic indicators. However, this is an approach we did not adopt because, as noted by (Angeon and Bates (2015, pg. 143), "Composite VR indexes do not explicitly refer to sustainable development concerns...”. In addition, Freudenberg (2003) states this method becomes unreliable when "soft" qualitative data are used. The Incorporation into our index of certain government policies which it has implemented to aid in its SD are data we deem to be qualitatively "soft". As such, we avoided the use of the Composite Vulnerability and Resilience (VR) Index as the basis of our index.

Another type of index that ultimately we applied uses what Freudenberg (2003) called "Thematic indicators." Freudenberg defines these thematic indicates as "individual indicators which are grouped together around a specific area or theme" (pg. 7). In this vein, our index is composed of a pertinent quantitative sustainability indicators that fall within the themes of social, economic, environmental and Climate Change incorporating Disaster Risk Reduction. With a common set of indicators, we can collect and interpret the data, and compare over time and geographies. By using an index, we can also transparently identify how and why each specific indicator is scored and how they collectively determine a country's overall progress to a sustainable society. In this article we use the Republic of Trinidad and Tobago (hereafter Trinidad/Tobago) as our case study of a small island developing state to both present its progress towards sustainable development and to test the applicability of this index. We selected Trinidad/Tobago because of its UN designation as SIDS (UN 2015), the availability of comprehensive and contemporary data, geographic location (Caribbean), ethnic makeup, and governmental structures. Finally, Trinidad/Tobago has been at the forefront of SIDS debates hosting conferences on SD in the Caribbean.

\section{The Study Area}

Trinidad and Tobago was inhabited before the arrival of European settlers by the Arawak and Cariban Indians (Ligon and Kupperman 2011; Boomert 2016). These indigenous populations either abandoned their homeland or their populations disappeared with the arrival of the European colonists and African slaves. The first European settlers were the Spanish but in early $19^{\text {th }}$ century it was incorporated into Great Britain. The colonial economy was initially based on sugar production using African slave labor. After emancipation in 1834, contract workers from India helped increase sugar production and developed the cocoa industry. Trinidad/Tobago attained their independence in 1962 and has a parliamentary system of governance. The 
population is 1,222,363 and the racial/ethnic makeup is East Indian (35.4\%), African (34.2\%), mixed (15.3\%), and mixed African/East Indian (7.7\%). The main drivers of the county's economy are fossil fuel processing and production funded by foreign investments are. Tourism, mostly based in Tobago, is a growing sector. With the economic strength provided by the fossil fuel industry the country is becoming one of the most affluent in the Caribbean.

Figure 1. Regional location and detailed map for Trinidad and Tobago. Detailed map of the island group is from Google Earth ${ }^{\circledR}$.

\section{Methodology}

\subsection{Development of Index for SIDS}

We developed an index as a means to measure the progress of the small island nation of Trinidad/Tobago towards the goal of sustainable development. Indices can simplify natural and/or anthropogenic realities that they seek to measure and represent (Alberti and Parker 1991; Lonegran et al. 2000; Mori and Christodoulou 2012). Our aim is to create an index that is not too burdensome and can be applied to other SIDS as a means of determining their progress towards a sustainable future. We created a set of indicators based on the $17 \mathrm{UN}$ sustainable development goals with 169 targets documented in Transforming Our World: The 2030 Agenda for Sustainable Development (UN 2015) and categorized them according to the three pillars of social, economic and environmental sustainable development. We created an additional category of Climate Change incorporating Disaster Risk Reduction (DRR) acknowledging the great vulnerability that it poses to SIDS and cuts across all three SD pillars. Table 1 shows the linkage of our index to the SD goals and what we consider are their most important affiliated targets.

Where available, we use the UN sustainability development goal targets as a starting point for developing our scoring system while simplifying the UN targets. This simplification is a strength in that it creates a flexible and comparable tool that can be easily applied and understood by many scientists, resource managers, and policy makers. But these simplifications can also be a limitation in that an index requires the quantification of all data and prioritizes the selection of some indicators over others. An example of this limitation is the case of infant mortality; for success the UN target is less than 12 deaths per 1000 live births. However, this static target does not allow for the recognition of a nation's steadily improving efforts to meet or exceed the standard (Babcicky 2013).

Table 1. Linkage between UN sustainable development goals and the SIDS sustainable development index.

\subsection{Scoring and weighting of the Indicators}

Table 2 shows our index scoring system. Where the UN had no definitions for quantitative values, we developed a scoring criterion based on numerical comparisons between selected developed and developing countries. For developed countries we used Scandinavian countries as a benchmark characterizing sustainable societies and countries in sub-Saharan 
Africa as those struggling with SD (UN 2016b). In our scoring system, a score of 1 implies little progress, 2 shows some progress, 3 shows significant progress while the maximum score of 4 demonstrates the achievement of the goal. However, in the case of policy specific indicators we give a score of 1 if the policy does not exist and a 4 if a policy has been formulated and implemented.

Each of the four major themes of social, economic, environmental and Climate Change incorporating Disaster Risk Reduction, were given the same weighting of 1 . We feel that all four have equal importance to the SD of any nation. For each themes indicators, if the data collected is strictly quantitative, such as life expectancy, that indicator is given a weight of 1 . However, if the indicator is scored according to the presence of policies or their success, that indicator receives a weight of 0.75 . By using this approach we recognize a certain degree of subjectivity in the "soft" qualitative data (Freudenberg (2003).

Table 2: Scoring system for the SIDS sustainable development index and the individual scores for Trinidad/Tobago.

\subsection{Data Collection}

The indicator data used in scores for the two SIDS case studies comes from various open sources: the CIA World Factbook, the United Nations Statistics, and the World Bank's (WB) World DataBank contain a wealth of information (CIA 2016; UN 2016b; WB 2016). The official websites of the Government of the Republic of Trinidad and Tobago (GoRTT), along with the United States Department of Energy (USDOE), were also useful sources. We collected additional data from newspapers and non-governmental organization reports and websites like the International Institute for Democracy and Electoral Assistance for voter turnout to score the index. We excluded data from commercial operations, personal websites, or blogs. Most of the data for the social, economic, and climate change indicators were open resources freely available. Data for the environmental indicators were less accessible, and in certain cases, we needed to process pertinent raw data to generate the required information for a particular indicator. For a complete list of sources for each indicator, see Table A1 in Appendix.

\section{Results and Discussion}

The collation of the indicators and their scores for each of the four categories of the index are shown in Table 2.

\subsection{Progress towards Social Sustainability Goals}

\section{Population}

While the population of Trinidad/Tobago has been slowly growing as births have exceeded deaths (averaging $<0.5 \%$ since 1995), population projections point to a decline for the next 10 years, (GoRTT 2016a) due to a net negative migration (7,600 nationals left GoRTT in 2015). Trinidad/Tobago has been experiencing an emigration (loss) of skilled labor (IOM 2016). 
A continual loss of skilled labor hinders SD and the GoRTT has not developed any programs to reduce this outflow (IOM 2016).

\section{Health}

Trinidad/Tobago is making progress towards providing adequate health care to its population but there are areas where improvement is needed such as maternal health and infant mortality. The nation performs poorly in both maternal health and infant mortality rates as it barely meets the minimum requirement of $<70 / 100,000$ live births and does not meet the target for infant mortality (11/1,000 lives births stipulated by the UN 2030 sustainable development goals). Trinidad/Tobago does have several governmental programs in place to improve population health. The Health Services Accreditation Council of Trinidad and Tobago (HSACTT) is designed improving health services efficiency and standards. The Social Sector Investment Programme (2012) aims to modernized and improve the health care system. Other initiatives include the Chronic Disease Risk Factor Screening Campaign, the Tobacco Control Act (2009) and the creation of mobile health Ministry of Planning and Sustainable Development (TTMPSD 2014).

\section{Education}

Trinidad/Tobago scores poorly in the school life expectancy target due to low net enrollment in secondary education (indicator 3.3). In response, the Medium Term Policy Framework, 2011-2014 affirmed the government's commitment to a quality education for all (GoRTT 2011a). The framework calls for a robust education system at elementary, secondary, and tertiary levels that matches the needs of current and future labor markets. It specifically focuses on the integration of information and communication technology throughout the school curriculum. Two such government efforts in this regard are the eConnect and Learn Programme (eCAL) and the Laptop for Every Child initiative. The government's goal of $60 \%$ enrollment in tertiary education was achieved in December 2013.

\section{Social Participation}

Regarding social participation, Trinidad/Tobago needs to increase the number of women elected to political office and voter turnout for local elections. According to the UN Human Development Report for 2015 women hold 24.7\% of seats in parliament (UNDP 2015). The GoRTT, through the Ministry of Gender, Youth and Child Development, has taken steps to address gender inequality by developing a National Gender Policy. The goal is to include all stakeholders including government, industry and the public in gender issues. However, the draft of this policy has been stalled for 15 years in parliament (UN Country Team for Trinidad and Tobago 2016). Despite being founding members of the Association of Caribbean Electoral Organisations (1998), an organization charged with improving voter turnout, there is no evidence that membership has actually increased public participation. The public has negative perceptions of government officials due to a lack of transparency (TTMPSD 2014). As part of the national government's Institutional Framework for Sustainable Development, GoRTT created the Civil Society Board (CSB), the Stakeholder Advisory Councils (SAC) and the Economic Development Board (EDB) as conduits for public involvement and consultation. 
These agencies aim to increase public participation, understanding, and transparency of the country's socio-economic transformation.

Trinidad/Tobago actively connects its unique cultural identities to supporting a thriving tourist industry. It has a number of ongoing and new initiatives promoting cultural heritage outlined in the 2015 Social Sector Investment Programme (GoRTT 2015). The newest effort is the creation of The Remember When Institute. Its function is to serve as a repository for "intangible cultural heritage such as traditional knowledge, folklore, intangible cultural heritage and cultural art forms" (GoRTT 2015, pg. 82).

\section{Housing}

The provision of quality and affordable housing is a fundamental step towards SD. While Trinidad/Tobago performs well in the index with regards to having policies promoting affordable housing and has high local land ownership rates, the actual supply of affordable and adequate housing continues to be a problem (TTMPSD, 2014). To address this, GoRTT provides grants, subsidies, mortgages, and housing for squatters (Squatter Regularisation Act 1998).

\section{Crime and Social Justice}

A major social issue for Trinidad/Tobago is the high homicide rate (TTMPSD 2014). As a result, GoRTT instituted the Citizen Security Programme, to reduce crime by restricting access to firearms and directing crime prevention efforts to high risk neighborhoods. This program implemented several institutional changes: (a) the Ministry of National Security improved its ability to plan, coordinate and manage violence and crime prevention projects; (b) the police force strengthened its training, management, and supervision structure; and (c) the development, coordination, and implementation of community-based preventive measures (GoRTT 2012, pg. $37)$.

Although Trinidad/Tobago has lower income inequality than other Caribbean states as measured by its Gini Index score, poverty rates are still high with $18.9 \%$ of the population living in poverty (TTMPSD 2014). The government has taken steps to address poverty levels through the Poverty Reduction Programme which provides small grants for people living in poverty or on welfare to start micro-businesses or receive skills training. Other initiatives to help eradicate poverty and increase worker rights include the Children's Life Fund, the Decent Work Policy, and the Programme of Action for Trinidad and Tobago (2011-2013) (TTMPSD 2014).

A fundamental human right of all children is freedom from violence, abuse, and torture. In contrast, the government of Trinidad/Tobago has been slow to implement child welfare legislation (score of 2). Only in 2012 was the Children's Act finally passed due to public pressure (GOTT-UNICEF 2014).

Violence against women is still common throughout the world (García-Moreno 2013) and Trinidad/Tobago shows a need for improvement (score of 2). According to a 2015 United States Department of State (USDS) report, despite protective laws, police apathy towards prosecuting criminal acts perpetrated against women and a general public acceptance of genderbased violence is prevalent (USDS 2015). An estimated 50\% of women in the nation were physically and/or sexually abused. These findings are highly detrimental to a sustainable society 
and accordingly, much improvement is required. The USDS report states that women have equal rights to men regarding the nation's laws although the pay-rates are unequal and favor men notably in the private and informal sectors. An initiative by the Ministry of Gender, Youth, and Child Development is sponsoring "income generation workshops for unemployed single mothers and nontraditional skills training for women" (USDS 2015). Furthermore, the World Bank Group's Women, Business and the Law 2016 report found that the GoRTT increased the limit of awards for small business disputes in the small claims courts. This increase unintentionally benefits women as they own many of the small businesses on the islands.

\section{Transportation}

While access to public transportation between towns and cities is adequate in Trinidad/Tobago, road safety is a problem (Table 2). In terms of transportation safety and security, Trinidad/Tobago is deemed the least safe country in the Caribbean (Zimmermann et al. 2012). These concerns limit ridership on the transit system. In an attempt to address the problem of road safety, Trinidad/Tobago, through amendments to the Motor Vehicles and Road Traffic Act is trying to improve road safety by tackling drunk driving with increased fines for traffic related offenses (GoRTT 2015). A review of city and national mass transit routes found that the bus transit system is poor in the capital of Trinidad/Tobago (Francke 2013). The regularity and reliability of these transportation services could not be ascertained and the GoRTT does not have any plans for further investment in public transportation programs (GoRTT 2016b). Due to the lack of incorporation of modern mass transit systems into current or planned road/rail networks (Sustainable transit systems), Trinidad/Tobago receives a score of 2.

\subsection{Progress towards Economic Sustainability Goals}

\section{Economic Performance}

Trinidad/Tobago's GDP per capita is higher than most of the other Caribbean SIDS although it suffers from high inflation rates. To improve the sustainability of its industry, the GoRTT requires its manufacturing industry to adopt Green Manufacturing Practices although the exact nature of these practices is vague (GoRTT 2012). Others initiatives exist, however, to expand environmentally friendly and clean manufacturing like the development of an AmmoniaUrea-Melamine (AUM) Complex, Methanol to Polypropylene-Polyolefins, and Midscale Liquidified Natural Gas. Paradoxically, the country still relies heavily on its fossil fuel industry for income generation and has goals of increasing production and pursuing new markets. This approach does not demonstrate a shift towards a greener, more sustainable economy.

\section{Food Security and Sustainable Agriculture}

In Trinidad/Tobago undernourishment is not a major concern as the country is less reliant on imported food because of efforts to increase its own agricultural resources (FAO 2015). For example, the government has instituted reforms to the agriculture and fisheries sectors to improve food security and promote sustainable agriculture (GoRTT, 2012). Fisheries sector initiatives are being implemented to better manage fish stock by including local stakeholder 
input and enhancing aquaculture production. A Draft Fisheries Management Bill (2011) is yet to be passed in law as of 2016.

\section{0-year framework of programs on sustainable consumption and production}

The 10-Year Framework of Programs (10YFP) on sustainable consumption and production arose from the 2002 WSSD's Johannesburg Plan of Implementation (UNEP 2016). This framework is a significant UN push for sustainable development globally and therefore we have included it in our index. Trinidad/Tobago has its own National Strategic Plan but we can find no evidence of the GoRTT specifically implementing this program (GoRTT 2014a).

\section{Energy Consumption}

Energy consumption in Trinidad/Tobago is not particularly high but crude oil is the dominant source of fuel for electricity production (CIA World Factbook 2016) which is to be expected as it produces and exports fossil fuels. In an attempt to diversify its energy production, GoRTT outlined strategic actions for the renewable energy and ecotourism industries in the 2011-2014 MTPF. Additionally, the GoRTT 2011 and 2012 budgets included incentives for the expansion of solar, wind, and waste-to-energy technologies.

\section{Workforce}

The high level of unemployment for both sexes is of concern. A high percentage of females in the workforce is a key measure of the UN Sustainability Development Goal 5 which states: "achieve gender equality and empower all women and girls" (UN 2015). Without this, economic growth is impeded with a reduction in household spending power. In this regard, Trinidad/Tobago scores well with high female participation in their respective workforces. Equal distribution of women in the workforce is significant in that demonstrates the potential of greater economic self-reliance for the female population.

\section{Remittances}

The economic impact of remittances is controversial. One school of thought is that it helps promote local industry and strengthen the economy (Brown1998; Connell and Conway 2000) while others suggests remittances hamper development because the population becomes too dependent on external revenue sources (Cuthbertson and Cole 1995). We take the former view and Trinidad/Tobago scores low (1) in the low amounts of remittances provided by migrants. The exact reason why these amounts are low is unclear though we suspect it may be due to the nation's relative wealth compared to other SIDS that have a greater need for remittances. Conversely, there may not be a culture of migrants sending back funds to families "back home".

\section{Telecommunications}


A modern national telecommunications system is considered essential for SD (Labelle 1995) and the GoRTT has made a major push towards telecommunications development (score of 2). It is developing a national information and communications technology strategy aimed at increasing broadband capability and modernizing governmental processes with the $i G o v$ Strategy. The government is also supporting public-private technology initiative through the construction of a Science and Technology Park (TamanaIntech Park) by the University of Trinidad and Tobago and the Cove Eco-Industrial Estate and Business Park in Tobago (GoRTT 2012).

\section{Sustainable Tourism}

The Global Sustainable Tourism Council (GSTC) defines sustainable tourism as travel that minimizes the impact on the environment and disruption of the local population. It lists four themes under this definition: 1) effective sustainability planning, 2) maximizing socio-economic benefits for local communities, 3) enhancing cultural heritage and 4) minimizing degradation of the environment (GSTC 2016).

The GORTT's National Tourism Policy (NTP) of 2010 provides an overview of the nation's tourism policies framework but lacks specific examples. Here are its four themes: 1) The Town and Country Planning Division and the Commissioner of State Lands will oversee the sustainability planning mandate; 2) Tourism development shall benefit all of the people of Trinidad/Tobago and effective local community involvement should be the basis of tourism growth. This includes human resource goals of gender equality, career development, and national labor standards; 3 ) The government supports the revival of cultural traditions, art, and the recording of endangered historical facts. Furthermore, the cultural, historical and recreational assets of Trinidad/Tobago must be integrated into the tourism industry planning; and 4) Tourism should minimize degradation of the environment. The government plans to continuously monitor the impacts on sensitive areas, utilize environmental impact assessments for all tourism-related projects require the Environmental Management Authority (EMA) and other agencies to develop a coordinated, country-wide environmental strategy. Because of the vague nature of the NTP, we see room for much improvement and assign a score of 2.

While the development of the tourism sector is a central pillar of Trinidad/Tobago's SD, much of the investment is foreign. Also, an over-dependence on tourism for revenue with a large portion of the GDP coming from this sector makes a nation's economy vulnerable to the whims of the global market. In this regard Trinidad/Tobago performs well (score 4) with tourism contributing only $7 \%$ of its GDP. The impact of climate change must also be considered when considering the impact of the over-reliance on tourism. With sea level rise being a real danger to most Caribbean islands, the predominance of tourist operations located along the coast places the future of tourism for SIDS in peril. With a one meter rise in sea level which leads to a $100 \mathrm{~m}$ retreat of the shoreline, $67 \%$ of Trinidad/Tobago coastal tourist properties will be damaged (Scott et al. 2012).

An additional issue of relying on tourism is that the economic trickle-down and benefits to local populations can be minimal, especially during periods of global downturns while tourist service sector jobs tend to be low paying and workers under-employed (Bishop 2010; Gmelch 2012; Lindsay and McQuaid 2004; Yahya et al. 2005). Trinidad/Tobago's National Tourism Policy (GoRTT 2010) has an integrated nation-wide tourism strategy. Unfortunately, there is 
little specific concrete actions outlined but more word usage of encourage, promote, enhance, engage and facilitate. The Vision 2020 Strategic Tourism Development Plan is another government initiative (GoRTT 2010). The World and Travel Tourism Council (WTTC) reviewed the plan and concluded it "...lacks specific targets based on statistical analysis which are vital for the monitoring of policy implementation" (WTTC 2014).

\section{Coastal and marine resources}

Coastal and marine resources, particularly the fisheries sector, are significant contributors to SIDS economies. Trinidad/Tobago with its Fisheries Act, 1975, and Draft of Integrated Coastal Zone Management, 2014 has policies to protect these resources and consequently have high scores for the three indicators. However, it is important to emphasize that laws and policies that are not implemented preclude the sustainable management of resources.

\section{Transportation}

An efficient and safe transportation system is a key factor in the SD of any nation (Figueroa and Ribeiro 2013). Table 4 indicates that the transportation infrastructure in Trinidad/Tobago is poor (50\% of roads are unpaved) These transport systems are important for moving goods and people and facilitating island tourism The quality of the road infrastructure of Trinidad/Tobago needs investment to improve its economic potential (Crotti and Misrahi 2015).

\subsection{Progress towards Environmental Sustainability Goals}

Freshwater resources

Trinidad/Tobago performs well in providing potable water and waste water collection for its populations (Table 2). Water resource management and development is spread across various government ministries and agencies. Water-related legislation include the Town and Country Planning Act (1960), Water and Sewerage Act (1965), Environmental Management Act (1995) and the Planning and Facilitation of Development Act (2014). The most progressive action to date is the National Integrated Water Resources Management Policy of 2005 which incorporated the concept of Integrated Water Resources Management and applies a more holistic, sustainable approach than more traditional technocratic methods (Rahaman and Varis 2005). Another important initiative was the establishment of the Environmental Management Authority in 2000 to regulate water resources in conjunction with the Water Resources Management Unit within the Ministry of Public Utilities. A major mandate was to reduce pressure on freshwater supplies by exploring the use of Sea Water Reverse Osmosis to provide water for industry use.

\section{Air Quality and Renewable Energy}

Trinidad/Tobago relies heavily on the use of fossil fuels for energy production (>90\%) and consequently have high GHG emissions. This reliance on fossil fuels has resulted in very low usage of renewable energy technologies. Currently, renewable energy technologies are underutilized in Trinidad/Tobago. The Ministry of Energy and Energy Affairs' Draft Renewable Energy Policy (2011) investigated the potential of renewables. The Framework for Development 
of a Renewable Energy Policy (GoRTT 2011b) looked into solar and wind energy, and biogas from combustion of landfill refuse. The government hoped these renewable energy sources could supplement the production and heavy reliance on natural gas. Trinidad/Tobago and other Caribbean states are investigating possible collaborations to promote the development and growth of renewable energy such as the Caribbean Renewable Energy Centre (CREC). With a concerted government effort, renewables could generate $5 \%$ of the peak demand for electricity by 2020 with wind energy being the most viable method (GoRTT 2011b).

\section{Biodiversity, Protected lands and Land Use}

Trinidad/Tobago has laws and regulations to protect natural habitats and adhere to international conventions pertaining to protected species. Consequently, it scores highly for the biodiversity indicators. The GoRTT has created the Biodiversity Strategy and Action Plan and the National Protected Areas Policy (www.biodiversity.gov.tt). The inclusion of the two environmental categories, Protected lands and Land Use, allows for a closer look at potential threats to the biodiversity of these nations that are not apparent biodiversity indicator alone. Trinidad/Tobago does not have sizeable territorial areas that are protected from development as protected terrestrial and marine zones amount to less than $10 \%$ of its territory. In addition, urban areas are expanding and forested areas diminishing. The GoRTT efforts at restoring and protecting coastal, marine and forest zones include the National Protected Areas Policy and the National Forest Policy (www.biodiversity.gov.tt) which fall under the auspices of the Integrated Coastal Zone Management and Rural Area Development Policy (2000).

The GoRTT has instituted various legislative measures to sustainably manage the country's land resources. The Town and Country Planning Act required the creation of a National Physical Development Plan (NPDP) designed to provide a policy framework for regional and local development plans. An important part of these plans are controlling land use, site development standards and building codes all of which help create a safer and more sustainable environment. The Planning and Facilitation of Development Act (2014) was created to address the conflict between the socio-economic and physical planning. The National Forest Policy is an example of GoRTT's attempts at restoring and protecting its forest resources.

\section{Coastal and marine environmental protection}

To take pressure off the traditional fisheries, Trinidad/Tobago has looked to aquaculture and mariculture programs as a means of moving towards more SD. The Ministry of Food Production, Land, and Marine Affairs is responsible for these endeavors, however, critics question the environmental sustainability of this approach as a result of coastal degradation from these commercial operations (Grigorakis and Rigos 2011). The protection of the nation's coastal marine resources falls under the Integrated Coastal Zone Management and Rural Area Development Policy (2000) which aims to minimize coastal pollution. The Fisheries Division and local organizations monitor/oversee these activities. In addition, the Marine Areas Preservation and Enhancement Act of 1970 (updated in 1996 and 2009) regulates marine areas such as coral reefs. The government is currently working on establishing an Integrated Coastal Zone Management Policy Framework, Strategies and Action Plan (GoRTT 2014b) that will include all stakeholders involved in the sustainable management of the island's marine resources. 


\section{Ecotourism}

Ecotourism, defined as "responsible travel that conserves the environment and sustains the well-being of local people" (The International Tourism Society 2016) is often touted as the most effective and environmentally friendly means of stimulating growth in the tourism industry (Bhuiyan et al. 2015; Hunt et al. 2015; Picard 2015). When evaluating the success of the ecotourism sector, we included the following criteria: 1) legal protection of natural environment and effective enforcement of these laws; 2) public attitudes; 3 ) government financial support; 4) quality of sites.

In the case of Trinidad/Tobago, the Ministry of Planning and the Economy's (MPE) 2012 document Working for Sustainable Development in Trinidad and Tobago is the most recent source of information regarding ecotourism (GoRTT 2012). Using the information gleaned from this report, the ecotourism sector suffers from inadequate enforcement of environmental legislation, public apathy in protecting the environment, insufficient finances, and environmental damage and degradation of ecotourism sites. The degradation of the Buccoo Reef Complex by offshore sewage releases is one such example. The country has a wealth of natural environments that can be tapped for ecotourism but this industry is still in its infancy. GoRTT has recently launched its Sustainable Eco-Trails Programme and promoted the development of Chaguaramas region (GoRTT 2010). The Draft Eco-Tourism Policy (2010) has not been formalized to date and the 2020 Strategic Tourism Development Plan does not provide a comprehensive overview of the industry (WTTC 2014). Based on this evidence we assign Trinidad/Tobago a score of 2.

\section{Household and commercial waste}

Due to the limited land area of SIDS, waste management is a particularly challenging endeavor. Siting of landfills often runs into opposition and funds for recycling programs are commonly insufficient. Poor coordination between three different governmental bodies hinders Trinidad /Tobago's waste management efforts. Furthermore, legislation is fragmented leading to an inefficient waste management system. Legislation includes the Public Health Ordinance the Litter Act (1973), and the Environmental Management Act (2000). Also, there are a number of draft bills and policies languish in various stages of review or have been shelved (for example the Beverage Container Bill 1999). Currently, only three landfills, all reaching capacity, accept solid waste in Trinidad. In an effort to reduce the waste flow, the Solid Waste Management Company Limited established in 1989 is responsible for managing waste recovery systems including markets for recyclable materials. Public apathy towards changing waste disposal practices challenges solid waste reduction. Recycling programs also need more governmental attention to reduce the waste generation (GoRTT 2012). However, collection of municipal and commercial waste is an essential component of SD and as Trinidad/Tobago collects waste from most households, its scores a 4 . Considering the problems of recycling outlined above, it scores a 1 .

\section{Transportation and gas emissions}

With a score of 3 for the Transportation sector, Trinidad/Tobago does not produce excessive transport energy consumption or $\mathrm{CO}_{2}$ gas emissions (27\%) (CIA World Factbook 
2016). Improvement in the reduction of $\mathrm{CO}_{2}$ emissions from transportation is possible as is evident in a similarly developed Caribbean nation of Barbados (a value of 1.5 emissions from consumption of petroleum (metric tons) per capita compared to that of 10.4 for

Trinidad/Tobago). Although GoRTT has set a target of a $30 \%$ reduction in $\mathrm{CO}_{2}$ emissions (below business-as-usual levels) the government has only provided a vague process on how it plans to attain this target (Gotta et al. 2015).

\subsection{Progress towards Climate Change and Disaster Management Sustainability Goals}

The overwhelming current and future threats of natural disasters and climate change to these Caribbean SIDS necessitates effective policies, adequate funding, and infrastructure (Table 2) (Lewsey et al. 2004; Solecki et al. 2011). Our section on Climate Change and Disaster Management indicators aims to measure a country's readiness and resilience. Common climate change mitigation indicators include targets for reducing $\mathrm{CO}_{2}$ emissions. While Trinidad/Tobago has targets in place, it is too early to tell whether these will be achieved although the slow adoption of renewable energy sources argues against such attainment.

Cooke (2014) provided detailed analysis of the disaster risk reduction measures being taken by GoRTT. While it has policies to reduce carbon emissions but work is still needed to improve their natural disaster resilience capacity. One policy implemented is the tightening of building codes, although relevant legislation is lacking, and the GoRTT is in the process of implementing other disaster risk reduction measures according to their BPoA and MSI plans.

Disaster risk reduction measures in GoRTT have been limited by several key factors that need to be addressed (Ramroop 2013). The lack of a comprehensive policy inhibits legal and institutional capacity. Legislation needs to strengthen building codes. Hazard, risk and vulnerability assessments are outdated and are in need of revision and implementation. Much of the data required for these assessments are lacking as is the monitoring of hazards, particularly those associated with climate change. A major focus of the government should be reducing the risk for vulnerable populations. Issues include single parent households, high unemployment rates, and a lack of public awareness to their exposure to risk. Finally, the network of early warning systems must be expanded (Cooke 2014).

\section{Overall Performance}

The purpose of this diagram is to give a visual representation to allow for a rapid assessment of how Trinidad/Tobago is successfully moving towards SD. The values depicted are the averages for each category. There is little difference between the Social, Economic and Environmental categories for Trinidad/Tobago. All three show that the nation requires a great deal of investment and changes in policy to improve its goal of being a sustainable society. The area of most concern is Climate Change and Disaster Management. With Caribbean nations being located in areas prone to tropical storms and much of its population located along the coastline, Trinidad/Tobago must take greater strides to reduce its vulnerability and augments its capacity to cope with future potential disasters. 
Figure 2. Summary of the performance for each sustainability category and overall score for Trinidad/Tobago.

\section{Index validity}

When considering the validity of a sustainable development index for SIDS, it must address all the major components outlined by the international conventions pertains to SD. As shown in Table 1, the categories and indicators we included are based on the goals and targets of the UN's requirements for sustainable development. In addition, with our focus on SIDS, we took into consideration the main components of sustainable development that are discussed in the National Assessment Reports required by the Barbados Plan of Action and the Mauritius Strategy for Further Implementation of the Programme of Action for Small Island Developing States. These reports outline the policies the nation has installed and where progress is still required to meet the action plans created by these conventions. We included their advances and remaining gaps in progress towards SD for the justification of our scoring for each indicator that were highlighted in these reports. With this inclusion and the foundation of the index being the framework of the UN sustainable development goals, we feel confident in the validity of our method for measuring progress of progress for SD of SIDS.

\section{Conclusions}

Since the 1990s, there has been a drive towards SD for both developed and developing nations. Some of the most vulnerable to economic turmoil, environmental degradation and social upheaval are Small Island Developing States (SIDS). A detailed analysis of the reasons behind this vulnerability are numerous and beyond the scope of the article. However, a lack of economic diversity, reliance on imports for basic needs, limited space, fiscal economic depression, poor or aging infrastructure, fragmented policies and low levels of interagency coordination are particular problems for these island states. With the focus of the UN on the SD of SIDS, the Trinidad/Tobago government is making a concerted effort to address the above problems through policies, national legislation and various international agreements. Through the application of this index, we provide a means of measuring progress towards achieving certain benchmarks of SD. SIDS regularly generate required SD progress reports, however, they tend to be more qualitative and lack concrete quantitative data. Consequently, the index attempts to rectify this deficiency by supplying these data in a form that is accessible to interested agencies and help direct efforts towards improving SD efforts through quantifiable goals or targets. 


\section{References}

Alberti M, Parker JD. 1991. Indices of environmental quality: the search for credible measures. Environ Impact Assess Rev. 11:95-101.

Angeon V. Bates S. 2015. Reviewing Composite Vulnerability and Resilience Indexes: A Sustainable Approach and Application. World Dev. 72:140-162.

Babcicky, P., 2013. Rethinking the foundations of sustainability measurement: the limitations of the Environmental Sustainability Index (ESI). Social indicators research, 113(1), pp.133-157.

Bhuiyan MAH, Siwar C, Ismail SM. 2015. Sustainability Measurement for Ecotourism Destination in Malaysia: A Study on Lake Kenyir, Terengganu. Soc Indicators Res. 1-17.

Bishop ML. 2010. Tourism as a Small-State Development Strategy Pier Pressure in the Eastern Caribbean? Prog Develop Stud. 10:99-114.

Boomert A. 2016. The indigenous peoples of Trinidad and Tobago from the first settlers until today. Casemate Publishers. Pennsylvania, USA

Braidotti R. 1994. Women, the environment and sustainable development: towards a theoretical synthesis. Zed Books. London, UK.

Briguglio L. 1995. Small-island Developing States and their Economic Vulnerabilities. World Dev. 23: 1615-32.

Brown RPC. 1998. Do migrants' remittances decline over time? Evidence from Tongans and Western Samoans in Australia. Contemp Pacific 10:107-51.

Byrne J. Inniss V. 2002. Island sustainability and sustainable development in the context of climate change. Sustainable development for island societies: Taiwan and the world.3-29.

Central Intelligence Agency (CIA). 2016. The World Factbook.

https://www.cia.gov/library/publications/the-world-factbook/

Connell J. Conway D. 2000. Migration and remittances in island microstates: a comparative perspective on the South Pacific and the Caribbean. Int J Urb Region Res. 24:52-78.

Cooke A. 2014. The Identification of Disaster Risk Reduction Opportunities for the DIPECHO Action Plan for the Caribbean 2015- 2016 UN Office of DRR

Crotti RO. Misrahi TI. 2015. The Travel \& Tourism Competitiveness Index 2015: GoRTT as a Resilient Contribution to National Development. The Travel \& Tourism Competitiveness Report. 2015:13-38

Cuthbertson S. Cole. R. 1995. Population growth in the South Pacific island states -implications for Australia. Australian Government Publishing Service, Canberra.

Figueroa MJ. Ribeiro SK. 2013. Energy for road passenger transport and sustainable development: assessing policies and goals interactions. Curr Opin Environ Sus. 5:152-162

Food and Agriculture Organization of the United Nations (FAO). 2015. FAO Statistical Pocketbook. World Food and Agriculture 2015.

Francke A. 2013. Why are you not cycling? - A case study for Trinidad and Tobago. $13^{\text {th }}$ World Conference on Transport Research, July 1518, 2013 - Rio de Janeiro, Brazil 
Freudenberg M. 2003. Composite indicators of country performance. OECD Science, Technology and Industry Working Papers, 2003/16, OECD Publishing, Paris

Ghina F. 2003. Sustainable development in small island developing states. Environ Dev Sus. 5:139-165.

Gmelch G. 2012. Behind the smile: the working lives of Caribbean tourism. Indiana University Press.

García-Moreno, C. 2013. Global and regional estimates of violence against women: prevalence and health effects of intimate partner violence and non-partner sexual violence. World Health Organization.

GSTC. 2016. Global Sustainable Tourism Council. www.gstcouncil.org

GoRTT. 2016a. Central Statistics Office. http://cso.planning.gov.tt/

GoRTT 2016b Public Sector Investment Programme

GoRTT. 2015. Act No.2 of 2015. Chap. 48:50, Motor Vehicles and Road Traffic Act. Government of Republic of Trinidad and Tobago

GoRTT. 2014a. Report of the Republic of Trinidad and Tobago. Third International Conference on Small Island Developing States - National Report. Ministry of Planning and Sustainable Development.

Government of Republic of Trinidad and Tobago.

GoRTT. 2014b. Integrated Coastal Zone Management (ICZM) DRAFT Policy Framework, 2014. Ministry Of Environment and Water Resources. Government of Republic of Trinidad and Tobago

GoRTT. 2012. Working for Sustainable Development in Trinidad and Tobago. Ministry of Planning and the Economy.

sustainabledevelopment.un.org/content/documents/1461Working\%20for\%20Sustainable\%20Developmen t\%20in\%20Trinidad\%20and\%20Tobago.pdf

GoRTT. 2011a. Medium Term Policy Framework, 2011-2014. Ministry of Planning and Economy.

Trinidad and Tobago 2016 UPR: Joint Submission from the

GoRTT. 2011b. Framework for Development of a Renewable Energy Policy for Trinidad and Tobago: A Report of the Renewable Energy Committee. Ministry of Energy and Energy Affairs. Government of Republic of Trinidad and Tobago.

GoRTT. 2010. National Tourism Policy of Trinidad and Tobago. Ministry of Tourism. Government of Republic of Trinidad and Tobago.

GOTT-UNICEF. 2014. Trinidad and Tobago Strategic Actions for Children and GOTT-UNICEF Work Plan 2013-2014).

Gota S, Huizenga C, Peet K, Kaar G. 2015. Intended Nationally-Determined Contributions (INDCs) Offer Opportunities for Ambitious Action on Transport and Climate Change. Partnership on Sustainable Low Carbon Transport November 24, 2015. Paris Process on Mobility and Climate.

Government of United States. 2015. Bureau of Democracy, Human Rights and Labor, United States Department of State (2015) Country Reports on Human Rights Practices for 2015: Barbados).

Grigorakis K, Rigos G. 2011. Aquaculture effects on environmental and public welfare-The case of Mediterranean mariculture. Chemosphere 85:899-919. 
Hunt CA, Durham WH, Driscoll L, Honey M. 2015. Can ecotourism deliver real economic, social, and environmental benefits? A study of the Osa Peninsula, Costa Rica. J Sus Tourism. 23:339-357.

IPCC (Intergovernmental Panel on Climate Change). 2007. IPCC Working Group II Fourth Assessment Report. Geneva: IPCC

IOM 2016. International Organization for Migration. www.iom.int/countries/trinidad-and-tobago.

Island Voices, Global Choices (2014). UN Conference on Small Island Development States. http://www.sids2014.org/index.php?menu=1537

Jones AM. 1997. Training for empowerment? A comparative study of nonformal education for women in small island countries. Compare 27:277-286.

Kabeer N. 2005. Gender equality and women's empowerment: A critical analysis of the third millennium development goal 1. Gend Dev. 13:13-24.

Kelman, I. 2006. Island Security and Disaster Diplomacy in the Context of Climate Change. Les Cahiers de la Sécurité 63:61-94.

Kelman I. 2014. No change from climate change: vulnerability and Small Island Developing States. Geogr J. 180:120-129.

Krantz L. 2001. The sustainable livelihood approach to poverty reduction. SIDA. Division for Policy and Socio-Economic Analysis.

Labelle H. 1995. Telecommunications and sustainable development 1. Inform Tech Dev. 6:.67-72.

Lewsey C, Cid G, Kruse E. 2004. Assessing climate change impacts on coastal infrastructure in the Eastern Caribbean. Marine Pol. 28:393-409.

Lindsay C, McQuaid RW. 2004. Avoiding the 'McJobs': Unemployed job seekers and attitudes to service work. Work, Emp Soc. 18:297-319.

Lonergan S, Gustavson K, Carter B. 2000. The index of human insecurity. Aviso 6:1-11.

Mori K, Christodoulou A. 2012. Review of sustainability indices and indicators: Towards a new City Sustainability Index (CSI). Environ Imp Assess Rev. 32:94-106.

Pelling M, Uitto JI. 2001. Small island developing states: natural disaster vulnerability and global change. Global Environmental Change Part B: Environ Haz. 3:49-62.

Picard D. 2015. Making ecotourism sustainable: refocusing on economic viability. Lessons learnt from the "Regional strategic action plan for coastal ecotourism development in the South Western Indian Ocean”. J Sus Tourism 23:819-837.

Rahaman MM, Varis O. 2005. Integrated water resources management: evolution, prospects and future challenges. Sus: Sci Practice, Policy, 1(1).

Ramroop S. 2013. Trinidad and Tobago: National progress report on the implementation of the Hyogo Framework for Action (2011-2013). Available at: (accessed 03.03. 15).

Revenga A, Shetty S. 2012. Empowering Women Is Smart Economics. Finance Dev. 49: 40-43. 
Sachs D. 2012. From millennium development goals to sustainable development goals. Lancet 379:22062211.

Scott D, Simpson MC, Sim R. 2012. The vulnerability of Caribbean coastal tourism to scenarios of climate change related sea level rise. J Sus Tourism 20:883-898.

Solecki W, Leichenko R, O’Brien K. 2011. Climate change adaptation strategies and disaster risk reduction in cities: connections, contentions, and synergies. Curr Opin Environ Sus. 3:135-141.

The International Tourism Society 2016. www.ecotourism.org

Trinidad and Tobago Ministry of Planning and Sustainable Development (TTMPSD). 2014. Report of the Republic of Trinidad and Tobago. Third International Conference on Small Island Developing States National Report).

Turvey R. 2007. Vulnerability assessment of developing countries: the case of small-island developing states. Dev Pol Rev. 25:243-264.

UNDP. 2015. Human Development Report 2015: Work for Human Development. United Nations Development Programme. http://hdr.undp.org/en/2015-report.

UNEP. 2016. Global Action for Sustainable Consumption and Production 10YFP. www.unep.org/10yfp.

UNEP. 2014. Status of Fuel Quality and Vehicle Emission Standards Latin America and the Caribbean http://www.unep.org/transport/pcfv/PDF/Maps Matrices/LAC/matrix/LAC FuelsVeh Feb2014.pdf

UN. 2016a. Sustainable Development Knowledge Platform: Sustainable Development Goals. https://sustainabledevelopment.un.org/?menu=1300

UN. 2016b. United Nations Statistics Department. unstats.un.org.

UN. 2016c. UN Women. lac.unwomen.org/en/noticias-y-

eventos/articulos/2015/07/barbados\#sthash.VyoJqHOr.dpuf).

UN 2015. Transforming our World: The 2030 Agenda for Sustainable Development United Nations, 2015. https://sustainabledevelopment.un.org/ post2015/ transformingourworld/publication.

UN. 2011. UN Country Team for Trinidad and Tobago. 2016. Universal Periodic Review of Trinidad and Tobago ("2011 UPR”). Government of Republic of Trinidad and Tobago.

UN. 2010. Barbados: The Ten Year Framework of Programmes on Sustainable Consumption and Production (Scp) Patterns. www.un.org/esa/dsd/dsd_aofw_ni/ni_pdfs/NationalReports/barbados/SCP.pdf

UN. 2005. United Nations General Assembly 2005. World Summit Outcome, Resolution A/60/1, adopted by the General Assembly on 15 September 2005. Retrieved on: 2009-02-17.

UN. 1992. Division of Sustainable Development. Agenda 21, the Rio Declaration on Environment and Development. United Nations Conference on Environment and Development Rio de Janerio, Brazil, 3 to 14 June 1992. 
Unterhalter E. 2005. Global inequality, capabilities, social justice: The millennium development goal for gender equality in education. Int J Educ Dev. 25:111-122.

USDS. 2015. Bureau of Democracy, Human Rights and Labor, United States Department of State (2015) Country Reports on Human Rights Practices for 2015: Trinidad and Tobago)

WB. 2016. World DataBank 2016; databank.worldbank.org/

World and Travel Tourism Council (WTTC). 2014. Travel and Tourism Economic Impact 2015 Trinidad and Tobago. https://www.wttc.org/-/media/files/reports/economic\%20impact\%20research/ countries\%202015/ trinidadandtobago2015.pdf

Yahya F, Parameswaran A, Ahmed I, Sebastian R. 2005. The economic cost of tourism in Maldives. Tourism (13327461), 53(1).

Zimmermann R, Lawes C, Svenson N. 2012. Caribbean Human Development Report 2012 Human Development and the Shift to Better Citizen Security. United Nations Development Programme. 


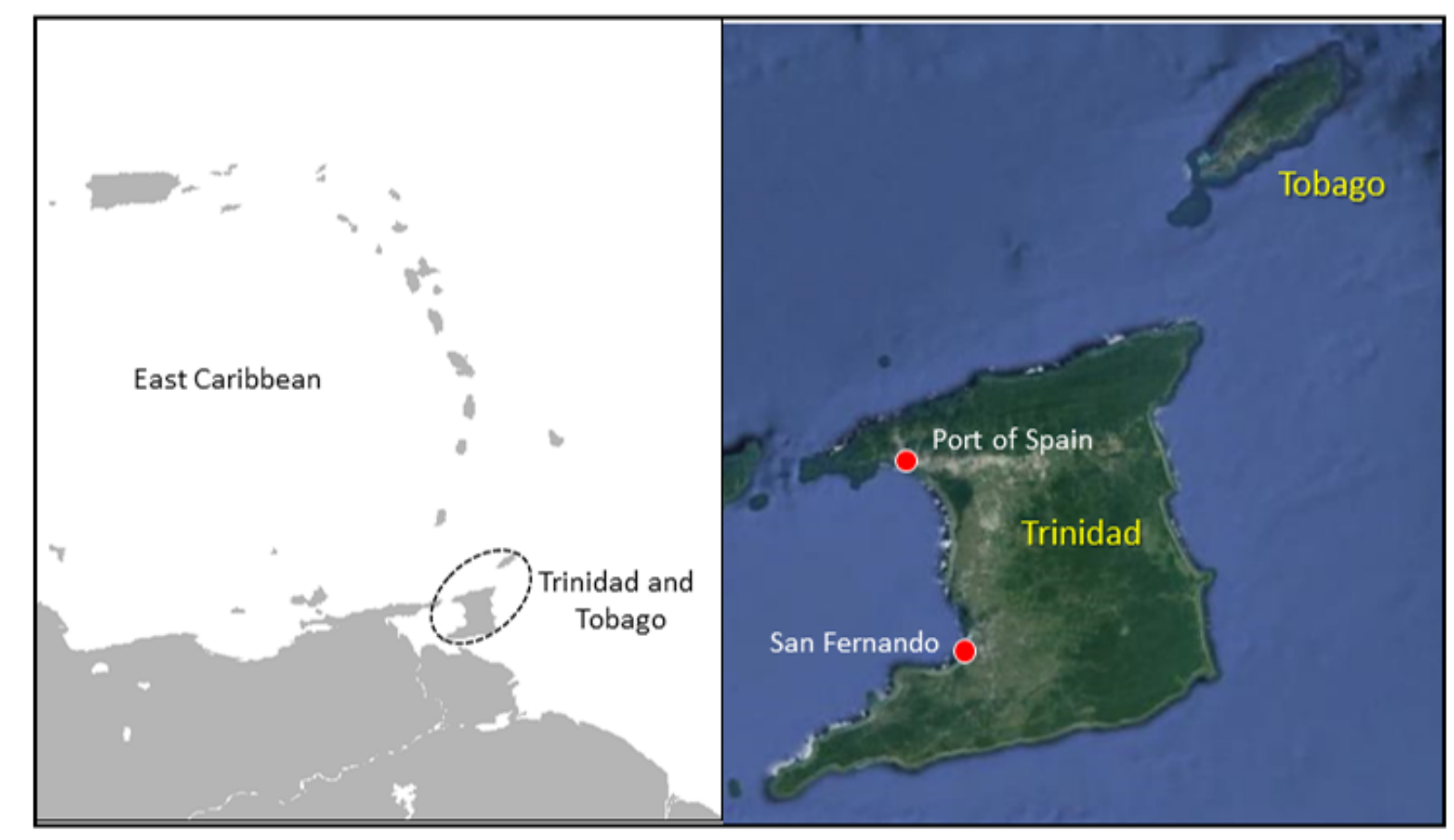




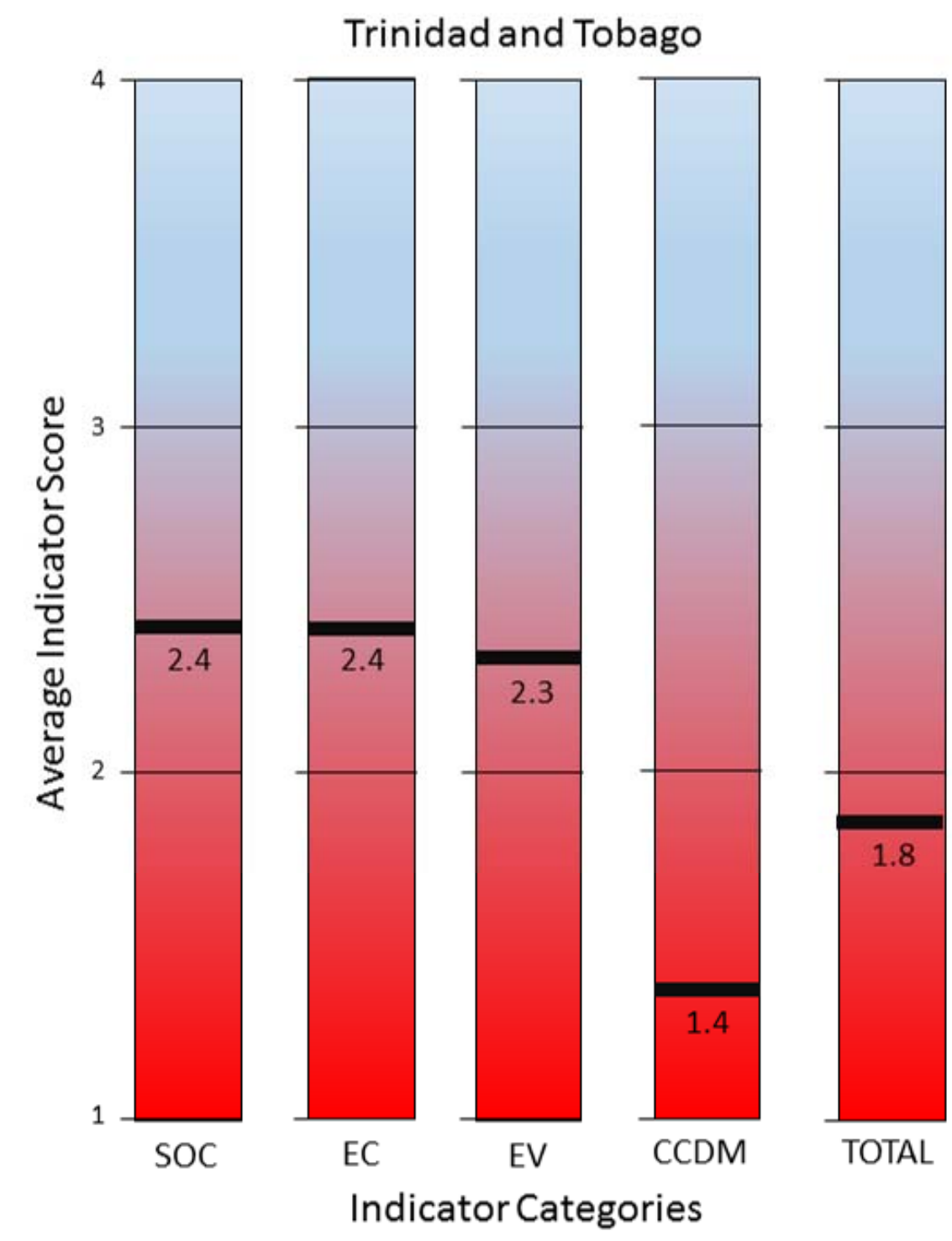




\begin{tabular}{|c|c|}
\hline Sustainable Development Goals and specific targets & \begin{tabular}{|l|} 
Index for Sustainable Development of SIDS \\
\end{tabular} \\
\hline $\begin{array}{l}\text { Goal 1. End poverty in all its forms everywhere: } \\
1.4 \text { All men and women, in particular the poor and the } \\
\text { vulnerable, have equal rights } \\
1.5 \text { reduce poor's exposure and vulnerability to climate } \\
\text { change and natural disasters }\end{array}$ & $\begin{array}{ll}- & \text { Availability of affordable housing - gov’t } \\
& \text { programs } \\
\text { - } & \text { Income inequality (Gini Index) } \\
\text { - } & \text { Unemployment rate (\% of labor force) } \\
\text { - } & \text { Female labor force (\% of total labor force) }\end{array}$ \\
\hline $\begin{array}{l}\text { Goal 2. End hunger, achieve food security and improved } \\
\text { nutrition and promote sustainable agriculture: } \\
\text { 2.2 End all forms of malnutrition } \\
\text { 2.4 Ensure sustainable food production systems and } \\
\text { implement resilient agricultural practices }\end{array}$ & $\begin{array}{ll}- & \text { Children under age of } 5 \text { years underweight } \\
\text { - } & \text { Institution of governmental food security and } \\
\text { - } & \text { sustainable } \\
\text { - } & \text { Prevalence of undernourished } \\
\end{array}$ \\
\hline $\begin{array}{l}\text { Goal 3. Ensure healthy lives and promote well-being for } \\
\text { all at all ages: } \\
\text { 3.1 Reduce the global maternal mortality } \\
\text { 3.2 Reduce preventable deaths of newborns and children } \\
\text { 3.3 End the epidemics of AIDS and other diseases } \\
\text { 3.6 Reduce traffic related deaths and injuries } \\
\text { 3.8 Better access to quality essential health-care services } \\
\text { 3.c Substantially increase health financing and the } \\
\text { recruitment, development, training and retention of the } \\
\text { health workforce }\end{array}$ & $\begin{array}{ll}- & \text { Average Life expectancy (yr) } \\
- & \text { Children under age of } 5 \text { years underweight } \\
& (\%) \\
\text { - } & \text { Low birth weights (\% of births) } \\
- & \text { Total Drinking water coverage (\% of total } \\
& \text { households) } \\
\text { - } & \text { Total Sanitation Coverage (\% of total } \\
& \text { households) } \\
\text { - } & \text { Emissions of Greenhouse gases (difference } \\
& 2000 \text { to 2012) }\end{array}$ \\
\hline $\begin{array}{l}\text { Goal 4. Ensure inclusive and equitable quality education } \\
\text { and promote lifelong learning opportunities for all: } \\
\text { 4.1 All girls and boys complete free, equitable and } \\
\text { quality primary and secondary } \\
\text { 4.4 Increase number of youth and adults who have } \\
\text { relevant skills, including technical and vocational skills } \\
\text { 4.5 Eliminate gender disparities in education and ensure } \\
\text { equal access } \\
\text { 4.6 Achieve literacy and numeracy }\end{array}$ & $\begin{array}{ll}- & \text { Adult literacy }(\% \text { of total } 15+\text { ) } \\
\text { - } & \text { Primary Education (\% completion rate of } \\
& \text { enrolled) } \\
\text { - } & \text { Net enrolment ratio in secondary education } \\
& (\%) \\
- & \text { School life expectancy, primary to tertiary } \\
& \text { (in years) }\end{array}$ \\
\hline $\begin{array}{l}\text { Goal 5. Achieve gender equality and empower all women } \\
\text { and girls: } \\
\text { 5.1 End discrimination against all women and girls } \\
5.5 \text { Ensure women's equal rights }\end{array}$ & $\begin{array}{ll}\text { - } & \text { Adult literacy (\% of total } 15+\text { ) } \\
\text { - } & \text { Primary Education (\% completion rate of } \\
\text { - } & \text { Net enrolled) } \\
\text { (\%) } & \\
\text { - } & \text { School life expectancy, primary to tertiary } \\
\text { (in years) } \\
\text { - } & \text { Women in political office (\%) individual } \\
& \text { gov't websites } \\
\text { - } & \text { Laws protecting women and children } \\
\end{array}$ \\
\hline $\begin{array}{l}\text { Goal 6. Ensure availability and sustainable management } \\
\text { of water and sanitation for all: } \\
6.1 \text { Equitable access to safe and affordable drinking } \\
\text { water } \\
6.2 \text { Adequate and equitable sanitation and hygiene } \\
\text { 6.3 Improve water quality } \\
\text { 6.4 Ensure sustainable withdrawals and supply of } \\
\text { freshwater } \\
\text { 6.6 Protect and restore water-related ecosystems }\end{array}$ & 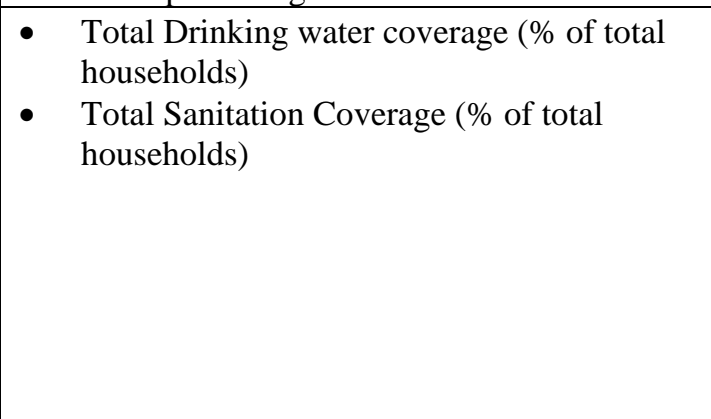 \\
\hline
\end{tabular}




\begin{tabular}{|c|c|}
\hline $\begin{array}{l}\text { Goal 7. Ensure access to affordable, reliable, sustainable } \\
\text { and modern energy for all: } \\
\text { 7.2 Increase use of renewable energy } \\
\text { 7.b Expand infrastructure and upgrade technology for } \\
\text { supplying modern and sustainable energy services }\end{array}$ & 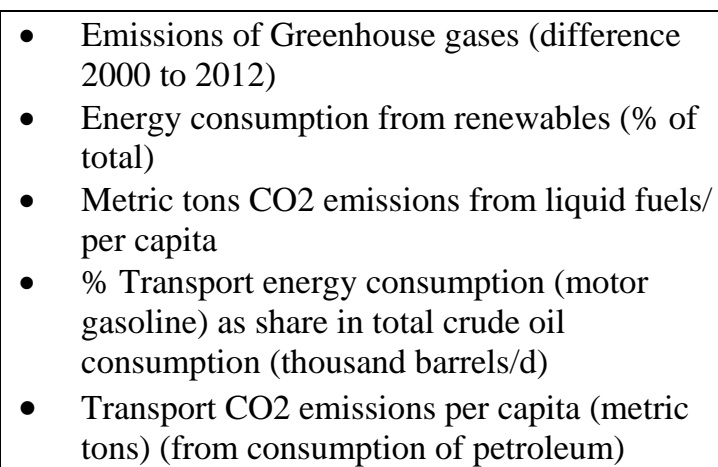 \\
\hline $\begin{array}{l}\text { Goal 8. Promote sustained, inclusive and sustainable } \\
\text { economic growth, full and productive employment and } \\
\text { decent work for all: } \\
\text { 8.1 Sustain increases in GDP growth per annum } \\
\text { 8.3 Promote decent jobs, entrepreneurship, creativity and } \\
\text { innovation } \\
\text { 8.5 Achieve full and productive employment and decent } \\
\text { work for all women and men } \\
\text { 8.9 Promote sustainable tourism }\end{array}$ & $\begin{array}{ll} & \text { Population trends (\% increase from previous } \\
\text { - } & \text { Near) } \\
& \text { migrants per 1,000 population.) } \\
\text { - } & \text { GDP per capita } \\
\text { - } & \text { Island Inflation (Consumer price index \%) } \\
\text { - } & \text { Budget: revenues/expenditure ratio } \\
\text { - } & \text { Unemplomic self-reliance: GDP/cost of gov't } \\
\text { - } & \text { Female labor force (\% of total labor force) } \\
\text { - } & \text { Personal remittances, received (\% of GDP) } \\
\text { - } & \% \text { population using internet } \\
- & \text { Established sustainable tourism management } \\
\text { - } & \text { plan } \\
& \text { Dependence of Economy on tourism (\% } \\
\text { - } & \text { Measures of sectoral strength (Ecotourism) } \\
\end{array}$ \\
\hline $\begin{array}{l}\text { Goal 9. Build resilient infrastructure, promote inclusive } \\
\text { and sustainable industrialization and foster innovation: } \\
\text { 9.4 Increase resource-use efficiency and adopt clean and } \\
\text { environmentally sound technologies } \\
\text { 9.5 Upgrade the technological capabilities of industrial } \\
\text { sectors } \\
\text { 9.b Support domestic technology development, research } \\
\text { and innovation } \\
\text { 9.c Increase affordable access to the Internet }\end{array}$ & $\begin{array}{ll}\text { - } & \text { GDP per capita } \\
\text { - } & \text { Island Inflation (Consumer price index \%) } \\
\text { - } & \text { Budget: revenues/expenditure ratio } \\
\text { - } & \text { Per capita electricity consumption (kWh) } \\
\text { - } & \text { Electricity from fossil fuels (\% total installed } \\
& \text { capacity) } \\
\text { - } & \text { Total Fossil Fuel Imports (barrel*/d) per } \\
& \text { capita / GDP (PPP) per capita } \\
\text { - } & \text { Paved roadways (\% of total) } \\
\text { - } & \text { Sustainable transit systems } \\
\end{array}$ \\
\hline $\begin{array}{l}\text { Goal 10. Reduce inequality within and among countries: } \\
\text { 10.2 Promote social, economic and political inclusion of } \\
\text { all } \\
\text { 10.3 Ensure equal opportunity and reduce inequalities of } \\
\text { outcome } \\
\text { 10.4 Adopt social protection policies, and progressively } \\
\text { achieve greater equality } \\
\text { 10.c Encourage migrant remittances }\end{array}$ & $\begin{array}{ll}- & \text { Women in political office (\%) individual } \\
& \text { gov't websites } \\
\text { - } & \text { Women in political office (\%) individual } \\
\text { - } & \text { gov't websites } \\
\text { - } & \text { Female labor force (\% of total labor force) } \\
\end{array}$ \\
\hline $\begin{array}{l}\text { Goal 11. Make cities and human settlements inclusive, } \\
\text { safe, resilient and sustainable: } \\
\text { 11.1 Ensure access for all to adequate, safe and affordable } \\
\text { housing } \\
\text { 11.2 Improve road safety, expand use of public transport }\end{array}$ & $\begin{array}{ll}\text { - } & \text { Preservation of historical cultural heritage } \\
\text { - } & \text { Availability of affordable housing - gov’t } \\
\text { - } & \text { programs } \\
\text { - } & \text { Recocal land ownership } \\
\end{array}$ \\
\hline
\end{tabular}




\begin{tabular}{|c|c|}
\hline $\begin{array}{l}\text { 11.4 Strengthen efforts to protect cultural and natural } \\
\text { heritage } \\
\text { 11.5 Reduce the number of deaths caused by disasters } \\
\text { 11.6 Improve air quality and municipal and other waste } \\
\text { management } \\
\text { 11.b Encourage policies towards inclusion, resource } \\
\text { efficiency, mitigation and adaptation to climate change, } \\
\text { resilience to disasters }\end{array}$ & \begin{tabular}{ll|}
- & Income inequality (Gini Index) \\
- & Roads deaths / 100,000 \\
- & $\%$ road deaths pedestrians \\
- & Access to public transport (\% urban areas \\
& served)
\end{tabular} \\
\hline $\begin{array}{l}\text { Goal 12. Ensure sustainable consumption and production } \\
\text { patterns: } \\
\text { 12.1 Implement the } 10 \text {-year framework of programmes } \\
\text { on sustainable consumption and production } \\
\text { 12.2 Achieve the sustainable management and efficient } \\
\text { use of natural resources } \\
\text { 12.4 Achieve environmentally sound management of } \\
\text { chemicals and all wastes } \\
\text { 12.5 Promote, reduction, recycling and reuse } \\
\text { 12.b Develop sustainable tourism }\end{array}$ & $\begin{array}{ll}- & \text { Implementation 10-year framework of } \\
\text { programs on sustainable consumption and } \\
\text { production } \\
\text { - } \\
\text { Energy consumption from renewables (\% of } \\
\text { - } \quad \text { Matal) } \\
\text { - } & \text { Househols recycled } \\
\end{array}$ \\
\hline $\begin{array}{l}\text { Goal 13. Take urgent action to combat climate change } \\
\text { and its impacts*: } \\
\text { 13.1 Strengthen resilience and adaptive capacity to } \\
\text { climate-related hazards and natural disasters in all } \\
\text { countries } \\
\text { 13.2 Integrate climate change measures into national } \\
\text { policies, strategies and planning } \\
\text { 13.3 Improve education, awareness-raising and human and } \\
\text { institutional capacity on climate change mitigation, } \\
\text { adaptation, impact reduction and early warning } \\
\text { 13.a Implement the commitment to the United Nations } \\
\text { Framework Convention on Climate Change } \\
\text { 13.b Promote raising capacity for effective climate change- } \\
\text { related planning }\end{array}$ & $\begin{array}{ll}\text { - } & \text { Gov’t policies in place to reduce carbon } \\
& \text { emissions } \\
\text { - } & \text { DRR integration into key sectors and } \\
& \text { agencies } \\
\text { - } & \text { Adequate funding (disaster recovery) } \\
\text { - } & \text { Laws governed by highest political office } \\
\text { - } & \text { Disaster preparedness plans } \\
\text { - } & \text { Early warning systems } \\
\text { - } & \text { Public information on DRR } \\
\text { - } & \text { Strategies for dealing with aftermath } \\
& \text { (protection of public health and vulnerable } \\
& \text { peoples) } \\
- & \text { Land use planning and building codes } \\
\end{array}$ \\
\hline $\begin{array}{l}\text { Goal 14. Conserve and sustainably use the oceans, seas } \\
\text { and marine resources for sustainable development: } \\
\text { 14.1 Reduce marine pollution of all kinds } \\
\text { 14.2 Sustainably manage and protect marine and coastal } \\
\text { ecosystems } \\
\text { 14.4 Regulate overfishing, illegal, unreported and } \\
\text { unregulated fishing and destructive fishing practices } \\
\text { 14.5 Conserve at least } 10 \text { per cent of coastal and marine } \\
\text { areas } \\
14.7 \text { Increase the economic benefits of sustainable } \\
\text { management of fisheries, aquaculture and tourism }\end{array}$ & $\begin{array}{ll} & \text { Delineated boundaries (Convention on the } \\
& \text { Law of the Sea) } \\
\text { - } & \text { Laws protecting fisheries } \\
- & \text { Monitoring of fish stocks } \\
- & \text { Regulation of coastal development } \\
- & \text { Urban footprint } \\
\text { - } & \text { Forests area }\end{array}$ \\
\hline $\begin{array}{l}\text { Goal 15. Protect, restore and promote sustainable use of } \\
\text { terrestrial ecosystems, sustainably manage forests, } \\
\text { combat desertification, and halt and reverse land } \\
\text { degradation and halt biodiversity loss: } \\
\text { 15.1 Ensure the conservation, restoration and sustainable } \\
\text { use of terrestrial and inland freshwater ecosystems } \\
\text { 15.2 Sustainably manage all forests and halt deforestation } \\
\text { 15.5 Reduce the degradation of natural habitats } \\
\text { 15.9 Integrate ecosystem and biodiversity values }\end{array}$ & \begin{tabular}{ll|}
- & Natural habitat preservation \\
- & Laws for protected species \\
- & Laws protecting coastal environment \\
- & Terrestrial and marine protected areas (\% of \\
& total territorial area)
\end{tabular} \\
\hline
\end{tabular}


15.a Finance the sustainable use and conservation of ecosystems ensuring biodiversity

Goal 16. Promote peaceful and inclusive societies for sustainable development, provide access to justice for all and build effective, accountable and inclusive institutions at all levels:

16.1 Reduce all forms of violence and related deaths 16.2 End all criminal acts directed towards children 16.3 Promote rule of law and ensure equal access to justice for all

16.6 Develop effective, accountable and transparent institution

16.7 Ensure responsive, inclusive, participatory and representative decision-making at all levels

Goal 17. Strengthen the means of implementation and

This goal is beyond the scope of our index.

- Availability of affordable housing - gov't programs

- $\quad \%$ Local land ownership

- Recorded homicides/100,000 people

- Income inequality (Gini Index)

- Laws for protection of children

revitalize the global partnership for sustainable development

Specific UN Sustainability targets* addressed by our index: (* we do not address all 169 target but those we deem most representative of the goals. The concepts of each target are summaries, not the entire text). 


\section{Strategic Sustainability Indicators: Measurable Outcomes}

\begin{tabular}{|c|c|c|c|c|c|}
\hline \multirow[t]{2}{*}{ Indicator } & \multicolumn{5}{|c|}{ Scoring } \\
\hline & 1 & 2 & 3 & 4 & Score \\
\hline \multicolumn{6}{|l|}{ S1 Population } \\
\hline 1.1. Population trends (\% increase from previous year) & $>2$ & $<0$ & Stable & $0-1$ & 4 \\
\hline $\begin{array}{l}\text { 1.2. Net migration (average annual net number of migrants per } 1,000 \\
\text { population) }\end{array}$ & $<-1$ & $>3$ & 2 & 0 & 1 \\
\hline \multicolumn{6}{|l|}{ S2 Health } \\
\hline \multicolumn{6}{|l|}{ 2.1. Average Life expectancy (yr): } \\
\hline Male & $<55$ & $55-60$ & $60-65$ & $>65$ & 3 \\
\hline Female & $<60$ & $60-65$ & $66-70$ & $>70$ & 4 \\
\hline 2.2. Maternal mortality rate, $\# / 100,000$ live births & $>70$ & $70-40$ & $39-10$ & $<10$ & 2 \\
\hline 2.3. Infant mortality rate, $\# / 1,000$ live births & $>12$ & $12-9$ & $8-5$ & $<5$ & 1 \\
\hline 2.4 Children under age of 5 years underweight (\%) & $>10$ & $10-5$ & $4-1$ & $<1$ & 3 \\
\hline 2.5. Low birth weights (\% of births) & $>13$ & $11-13$ & $8-10$ & $<8$ & 3 \\
\hline \multicolumn{6}{|l|}{ S3 Education } \\
\hline \multicolumn{6}{|l|}{ 3.1. Adult literacy (\% of total $15+$ ) } \\
\hline Female & $<90$ & $90-95$ & $95-99$ & 100 & 4 \\
\hline Male & $<90$ & $90-95$ & $95-99$ & 100 & 4 \\
\hline \multicolumn{6}{|l|}{ 3.2. Primary Education (\% completion rate of enrolled) } \\
\hline Female & $<80$ & $80-89$ & $90-99$ & 100 & 3 \\
\hline Male & $<80$ & $80-89$ & $90-99$ & 100 & 3 \\
\hline \multicolumn{6}{|l|}{ 3.3. Net enrolment ratio in secondary education (\%) } \\
\hline Female & $<70$ & $70-80$ & $81-90$ & $>90$ & 2 \\
\hline Male & $<70$ & $70-80$ & $81-90$ & $>90$ & 1 \\
\hline \multicolumn{6}{|l|}{ 3.4. School life expectancy, primary to tertiary (in years) } \\
\hline Female & $<10$ & $10-12$ & $13-15$ & $>16$ & 2 \\
\hline Male & $<10$ & $10-12$ & $13-15$ & $>16$ & 2 \\
\hline \multicolumn{6}{|l|}{ S4 Social Participation } \\
\hline $\begin{array}{l}\text { 4.1. No. of people voting in local elections (\% voter turnout of total } \\
\text { registered voters) }\end{array}$ & $<60$ & $60-70$ & $70-80$ & $>80$ & 2 \\
\hline 4.2. Women in political office (\%) individual gov't websites & $<15$ & $16-29$ & $30-45$ & $>45$ & 3 \\
\hline 4.3. Preservation of historical cultural heritage* & No & & & Yes & 4 \\
\hline \multicolumn{6}{|l|}{ S5 Housing } \\
\hline 5.1. Availability of affordable housing - gov't programs* & No & & & Yes & 4 \\
\hline 5.2. \% Local land ownership & $<35$ & $36-50$ & $51-70$ & $>70$ & 4 \\
\hline
\end{tabular}




\begin{tabular}{|c|c|c|c|c|c|}
\hline \multicolumn{6}{|l|}{ S6 Crime and Social Justice } \\
\hline 6.1. Recorded homicides $/ 100,000$ people & $>20$ & $10-20$ & $5-9$ & $<5$ & 1 \\
\hline 6.2. Income inequality (Gini Index) & $>50$ & $41-50$ & $31-40$ & $<30$ & 1 \\
\hline 6.3. Laws for protection of children* & None & $\begin{array}{l}\text { Only very recent } \\
\text { action }\end{array}$ & Strong laws & $\begin{array}{l}\text { Strong laws } \\
\text { plus specific } \\
\text { facilities for } \\
\text { child safety }\end{array}$ & 0.75 \\
\hline 6.4. Laws for protection of woman* & None & $\begin{array}{l}\text { Only very recent } \\
\text { action or laws in- } \\
\text { place ineffective }\end{array}$ & Strong laws & $\begin{array}{l}\text { Strong laws } \\
\text { plus facilities } \\
\text { specific to } \\
\text { women safety }\end{array}$ & 0.75 \\
\hline \multicolumn{6}{|l|}{ S7 Transportation } \\
\hline 7.1. Roads deaths / 100,000 & $>15$ & $11-15$ & $5-10$ & $<5$ & 1 \\
\hline 7.2. \% road deaths pedestrians & $>25$ & $24-20$ & $19-15$ & $<15$ & 1 \\
\hline 7.3. Sustainable transit systems* & $\begin{array}{l}\text { No mass transit } \\
\text { systems }\end{array}$ & $\begin{array}{l}\text { Outdated Mass } \\
\text { transit systems }\end{array}$ & $\begin{array}{l}\text { Effective Mass } \\
\text { transit systems }\end{array}$ & $\begin{array}{c}\text { Rapid rail/bus } \\
\text { Mass transit } \\
\text { systems }\end{array}$ & 0.75 \\
\hline \multicolumn{6}{|l|}{ E1 Economic Performance } \\
\hline 8.1. GDP per capita & declining & stable & $\begin{array}{l}\text { Increase } 1-2 \% \\
\text { per year }\end{array}$ & $\begin{array}{c}\text { Increase }>2 \% \\
\text { per year }\end{array}$ & 4 \\
\hline 8.2. Island Inflation (Consumer price index \%) & $>10$ & $5-10$ & $3-5$ & 2 & 2 \\
\hline 8.3. Budget: revenues/expenditure ratio & $<0.75$ & $0.75-0.9$ & $0.9-1$ & $>1$ & 2 \\
\hline 8.4. Economic self-reliance: GDP/cost of gov't & $<1$ & $1-2$ & $3-4$ & $>4$ & 2 \\
\hline \multicolumn{6}{|l|}{ E2 Food security and sustainable agriculture programs } \\
\hline 9.1. Institution of governmental food security and sustainable* & No & & & Yes & 3 \\
\hline 9.2. Prevalence of undernourished (\% of population) 2011-2016 & $>15$ & $10-15$ & $9-5$ & $<5$ & 3 \\
\hline 9.3. Food production index & $>-10$ & $-1-10$ & $0-20$ & $>20$ & 3 \\
\hline \multicolumn{6}{|c|}{ E3 10-year framework of programs on sustainable consumption and production } \\
\hline 10.1 Program ratified and implemented with related initiatives* & No & & & Yes & 0.75 \\
\hline \multicolumn{6}{|l|}{ E4 Energy Consumption } \\
\hline 11.1. Per capita electricity consumption (kWh) & $>10,000$ & $8-10,000$ & $5-7,000$ & $<5,000$ & 3 \\
\hline 11.2. Electricity from fossil fuels (\% total installed capacity) & $>80$ & $60-79$ & $30-59$ & $<30$ & 1 \\
\hline $\begin{array}{l}11.3 \text { Total Fossil Fuel Imports (barrel**/d) per capita / GDP (PPP) per } \\
\text { capita }\end{array}$ & $>5$ & $4-2$ & 1 & $<1$ & 1 \\
\hline \multicolumn{6}{|l|}{ E5 Workforce } \\
\hline \multicolumn{6}{|l|}{ 12.1. Unemployment rate (\% of labor force) } \\
\hline Female & $>10$ & $5-10$ & $2-5$ & $<2$ & 2 \\
\hline Male & $>10$ & $5-10$ & $2-5$ & $<2$ & 3 \\
\hline 12.2. Female labor force (\% of total labor force) & $<25$ & $25-40$ & $41-40$ & 50 & 3 \\
\hline
\end{tabular}




\begin{tabular}{|c|c|c|c|c|c|}
\hline \multicolumn{6}{|l|}{ E6 Remittances } \\
\hline 13.1. Personal remittances, received (\% of GDP) & $<5$ & $6-10$ & $11-15$ & $>15$ & 1 \\
\hline \multicolumn{6}{|l|}{ E7 Telecommunications } \\
\hline 14.1. \% population using internet & $<50$ & $50-69$ & $70-89$ & $>90$ & 2 \\
\hline \multicolumn{6}{|l|}{ E8 Tourism } \\
\hline 15.1 Established sustainable tourism management plan & No & & & Yes & 2 \\
\hline 15.2. Dependence of Economy on tourism (\% GDP) & $>50$ & $49-35$ & $34-25$ & $<25$ & 3 \\
\hline \multicolumn{6}{|l|}{ E9 Coastal and Marine Resources } \\
\hline 16.1. Delineated boundaries (Convention on the Law of the Sea)* & No & & & Yes & 3 \\
\hline 16.2. Laws protecting fisheries* & No & & & Yes & 3 \\
\hline 16.3. Monitoring of fish stocks* & No & & & Yes & 3 \\
\hline \multicolumn{6}{|l|}{ E10 Transportation } \\
\hline 17.1. Paved roadways (\% of total) & $<50$ & $50-70$ & $70-90$ & $>90$ & 1 \\
\hline 17.2. Urban areas served by mass transit (\%) & $<50$ & $50-70$ & $70-90$ & $>90$ & 4 \\
\hline \multicolumn{6}{|l|}{ EV1 Water Resources } \\
\hline 18.1. Total Drinking water coverage (\% of total households) & $<75$ & $75-90$ & $90-99$ & 100 & 3 \\
\hline 18.2. Total Sanitation Coverage (\% of total households) & $<75$ & $75-90$ & $90-99$ & $<100$ & 3 \\
\hline \multicolumn{6}{|l|}{ EV2 Air Quality } \\
\hline 19.1. Emissions of Greenhouse gases (difference 2000 to 2012) & $\uparrow$ & stable & $\downarrow$ & & 1 \\
\hline \multicolumn{6}{|l|}{ EV3 Renewable Energy } \\
\hline 20.1. Energy consumption from renewables (\% of total) & $<10$ & $10-20$ & $21-30$ & $>30$ & 1 \\
\hline \multicolumn{6}{|l|}{ EV4 Biodiversity } \\
\hline 21.1. Natural habitat preservation* & No & & & Yes & 3 \\
\hline 21.2. Laws for protected species* & No & & & Yes & 3 \\
\hline \multicolumn{6}{|l|}{ EV5 Coastal and Marine Environments } \\
\hline 22.1. Laws protecting coastal environment ${ }^{*}$ & No & & & Yes & 3 \\
\hline 22.2. Marine Wildlife Reserves* & No & & & Yes & 3 \\
\hline 22.3. Regulation of coastal development* & No & & & Yes & 3 \\
\hline \multicolumn{6}{|l|}{ EV6 Protected areas } \\
\hline 23.1. Terrestrial and marine protected areas (\% of total territorial area) & $<5$ & $5-10$ & $11-15$ & $>15$ & 4 \\
\hline \multicolumn{6}{|l|}{ EV7 Land Use } \\
\hline 24.1. Urban footprint & $\uparrow$ & stable & $\downarrow$ & & 1 \\
\hline 24.2. Forests area & $\downarrow$ & stable & $\uparrow$ & & 1 \\
\hline \multicolumn{6}{|l|}{ EV8 Ecotourism } \\
\hline $\begin{array}{l}\text { 25.1. Measures of sectoral strength (see below): number of measures } \\
\text { with high level of strength. }\end{array}$ & 1 & 2 & 3 & 4 & 2 \\
\hline \multicolumn{6}{|l|}{ EV9 Household \& Commercial Waste } \\
\hline 26.1. Household/Commercial waste collected (\% of total) & $<50$ & $50-70$ & $70-90$ & $>90$ & 4 \\
\hline $\begin{array}{l}\text { 26.2. Materials recycled (If no data available assume recycling not a high } \\
\text { priority for state so could give them a score of } 1 \text { ) }\end{array}$ & $<10 \%$ & $10-20 \%$ & $20-40 \%$ & $>40 \%$ & 1 \\
\hline
\end{tabular}




\begin{tabular}{|c|c|c|c|c|c|}
\hline \multicolumn{6}{|l|}{ EV10 Transport } \\
\hline 27.1. Metric tons CO2 emissions from liquid fuels/ per capita & $>10$ & $5-10$ & $1-4$ & $<1$ & 1 \\
\hline $\begin{array}{l}\text { 27.2. \% Transport energy consumption (motor gasoline) as share in total } \\
\text { crude oil consumption (thousand barrels/d) }\end{array}$ & $>50$ & $30-49$ & $15-29$ & $<15$ & 3 \\
\hline $\begin{array}{l}\text { 27.3. Transport } \mathrm{CO} 2 \text { emissions per capita (metric tons) (from } \\
\text { consumption of petroleum }+\delta \text { ) }\end{array}$ & $>12$ & $9-12$ & $4-8$ & $<4$ & 3 \\
\hline \multicolumn{6}{|l|}{ CC1 Climate Change and Disaster Management } \\
\hline 28.1. Gov't policies in place to reduce carbon emissions* & No & & & Yes & 2.25 \\
\hline \multicolumn{6}{|c|}{ Resilience building to climate change-related disasters through disaster risk reduction (DRR) supported by Gov't legislation } \\
\hline 28.2. DRR integration into key sectors and agencies * & None & Inadequate & Need updating & Yes & 0.75 \\
\hline 28.3. Adequate funding (disaster recovery)* & None & $\begin{array}{l}\text { Total external } \\
\quad \text { funding }\end{array}$ & $\begin{array}{c}\text { Most DRR } \\
\text { agencies } \\
\text { internally funded }\end{array}$ & $\begin{array}{c}\text { All DRR } \\
\text { agencies } \\
\text { internally fully } \\
\text { funded } \\
\end{array}$ & 0.75 \\
\hline 28.4. Laws governed by highest political office* & No & & & Yes & 0.75 \\
\hline 28.5. Comprehensive, up-to-date risk assessment * & None & Most basic & Need updating & $\begin{array}{c}\text { Current and } \\
\text { comprehensiv } \\
\mathrm{e}\end{array}$ & 1.5 \\
\hline 28.6. Disaster preparedness plans * & None & Most basic & Need updating & $\begin{array}{c}\text { Current and } \\
\text { comprehensiv } \\
\mathrm{e}\end{array}$ & 1.5 \\
\hline 28.7. Early warning systems* & None & Poor coverage & $\begin{array}{l}\text { Most nation } \\
\text { served }\end{array}$ & $\begin{array}{l}\text { All nation } \\
\text { served }\end{array}$ & 1.5 \\
\hline 28.8. Public information on DRR* & None & Minimal & $\begin{array}{c}\text { Poorly } \\
\text { disseminated }\end{array}$ & $\begin{array}{l}\text { Entire nation } \\
\text { informed }\end{array}$ & 1.5 \\
\hline $\begin{array}{l}\text { 28.9. Strategies for dealing with aftermath (protection of public health } \\
\text { and vulnerable peoples)* }\end{array}$ & None & Inadequate & $\begin{array}{c}\text { Areas need } \\
\text { improvement }\end{array}$ & $\begin{array}{l}\text { Nation fully } \\
\text { prepared }\end{array}$ & 0.75 \\
\hline 28.10. Landuse planning and building codes* & None & Inadequate & $\begin{array}{c}\text { Adequate but } \\
\text { weakly enforced }\end{array}$ & Fully enforced & 2.25 \\
\hline
\end{tabular}

* Weighting of 0.75

** barrels of total crude oil and refined petroleum products

+ Assumption that majority of consumption of petroleum from vehicles

$\delta$ Category value based emission levels of developed countries with fuel efficiency standards. Most values $\sim 4$ metric tons. 
Table S1. Sources of Indicators Scores for SIDs Sustainability Index

\begin{tabular}{|c|c|}
\hline Indicator & Sources of information \\
\hline \multicolumn{2}{|l|}{ S1 Population } \\
\hline All indicators & www.cia.gov/library/publications/resources/the-world-factbook/index.html \\
\hline \multicolumn{2}{|l|}{ S2 Health } \\
\hline All indicators & $\begin{array}{l}\text { www.cdc.gov/phppo/inpho/profile/vi_1_1.htm } \\
\text { www.cia.gov/library/publications/resources/the-world-factbook/index.html }\end{array}$ \\
\hline \multicolumn{2}{|l|}{ S3 Education } \\
\hline All indicators & $\begin{array}{l}\text { unstats.un.org/unsd/demographic/products/socind/default.htm; } \\
\text { databank.worldbank.org/data/reports.aspx?source=world-development- } \\
\underline{\text { indicators\#, }} \\
\text { www.cia.gov/library/publications/resources/the-world-factbook/index.html }\end{array}$ \\
\hline \multicolumn{2}{|l|}{ S4 Social Participation } \\
\hline $\begin{array}{l}\text { No. of people voting in local elections (\% voter turnout of total registered } \\
\text { voters) }\end{array}$ & $\underline{\text { www.idea.int/vt/ }}$ \\
\hline Women in political office (\%) individual gov't websites & hdr.undp.org/en/2015-report \\
\hline Preservation of historical cultural heritage & finance.gov.tt/wp-content/uploads/2014/09/SSIP-2015.pdf \\
\hline \multicolumn{2}{|l|}{ S5 Housing } \\
\hline Availability of affordable housing - gov’t programs & $\begin{array}{l}\text { sustainabledevelopment.un.org/content/documents/1169242Final\%20T\&T\%20re } \\
\text { port.pdf }\end{array}$ \\
\hline$\%$ Local land ownership & www.doi.gov/oia/reports/upload/USVI-CEDS-2009-2.pdf \\
\hline
\end{tabular}




\begin{tabular}{|c|c|}
\hline \multicolumn{2}{|l|}{ S6 Crime and Social Justice } \\
\hline Recorded homicides/100,000 people & $\begin{array}{l}\text { www.unodc.org/documents/data-and-analysis/Crime- } \\
\text { statistics/International_Statistics_on_Crime_and_Justice.pdf }\end{array}$ \\
\hline Income inequality (Gini Index) & www.bb.undp.org/ \\
\hline Laws for protection of children \& women & $\begin{array}{l}\text { sustainabledevelopment.un.org/content/documents/1169242Final\%20T\&T\%20re } \\
\text { port.pdf } \\
\text { www.unicef.org/easterncaribbean/ECAO_TNT_Strategic_Actions_for_Children } \\
\text {.pdf }\end{array}$ \\
\hline \multicolumn{2}{|l|}{ S7 Transportation } \\
\hline All indicators & $\begin{array}{l}\text { Government of Republic of Trinidad and Tobago Act No.2 of 2015. Chap. 48:50, } \\
\text { Motor Vehicles and Road Traffic Act. } \\
\text { www.finance.gov.tt/public-sector-investment-programme-2017 }\end{array}$ \\
\hline \multicolumn{2}{|l|}{ E1 Economic Performance } \\
\hline GDP per capita & $\begin{array}{l}\text { data.worldbank.org/indicator/NY.GDP.PCAP.CD } \\
\text { www.bea.gov/newsreleases/general/terr/2014/vigdp_081914.pdf }\end{array}$ \\
\hline Island Inflation (Consumer price index \%) & www.global-rates.com/economic-indicators/inflation/inflation.aspx \\
\hline $\begin{array}{l}\text { Budget: revenues/expenditure ratio \& Economic self-reliance: GDP/cost of } \\
\text { gov’t }\end{array}$ & www.cia.gov/library/publications/resources/the-world-factbook/index.html \\
\hline \multicolumn{2}{|l|}{ E2 Food security and sustainable agriculture programs } \\
\hline Institution of governmental food security and sustainable & $\begin{array}{l}\text { sustainabledevelopment.un.org/content/documents/1461Working\%20for\%20Sust } \\
\text { ainable\%20Development\%20in\%20Trinidad\%20and\%20Tobago.pdf }\end{array}$ \\
\hline Prevalence of undernourished \& Food production index 2011-2016 & www.fao.org/3/a-i4691e.pdf \\
\hline
\end{tabular}




\begin{tabular}{|c|c|}
\hline \multicolumn{2}{|c|}{ E3 10-year framework of programs on sustainable consumption and production } \\
\hline Program ratified and implemented with related initiatives & www.un.org/esa/dsd/dsd_aofw_ni/ni_pdfs/NationalReports/barbados/SCP.pdf \\
\hline \multicolumn{2}{|l|}{ E4 Energy Consumption } \\
\hline capita electricity consumption $(\mathrm{kWh})$ & data.worldbank.org/indicator/EG.USE.ELEC.KH.PC \\
\hline $\begin{array}{l}\text { Electricity from fossil fuels ( } \% \text { total installed capacity) \& Total Fossil Fuel } \\
\text { Imports (barrel*/d) per capita / GDP (PPP) per capita }\end{array}$ & www.cia.gov/library/publications/resources/the-world-factbook/index.html \\
\hline \multicolumn{2}{|l|}{ E5 Workforce } \\
\hline All indicators & databank.worldbank.org/data/reports.aspx?source=world-development-indicators \\
\hline \multicolumn{2}{|l|}{ E6 Remittances } \\
\hline Personal remittances, received (\% of GDP) & data.worldbank.org/indicator/BX.TRF.PWKR.DT.GD.ZS \\
\hline \multicolumn{2}{|l|}{ E7 Telecommunications } \\
\hline$\%$ population using internet & www.internetworldstats.com \\
\hline \multicolumn{2}{|l|}{ E8 Tourism } \\
\hline Established sustainable tourism management plan & www.ema.co.tt/new/images/policies/tourism_policy.pdf \\
\hline Dependence of Economy on tourism (\% GDP) & www.wttc.org \\
\hline \multicolumn{2}{|l|}{ E9 Coastal and Marine Resources } \\
\hline All indicators & $\begin{array}{l}\text { www.ima.gov.tt/home/images/docs/Ingrated_Coastal_Zone_Mment_Policy_Fra } \\
\text { mework_Minister_April_2014.pdf }\end{array}$ \\
\hline \multicolumn{2}{|l|}{ E10 Transportation } \\
\hline Paved roadways ( $\%$ of total) & www.cia.gov/library/publications/resources/the-world-factbook/index.html \\
\hline
\end{tabular}




\begin{tabular}{|c|c|}
\hline Urban areas served by mass transit (\%) & $\begin{array}{l}\text { Bus route documents } \\
\text { www.discover- } \\
\text { tt.net/general_info/public transport_service_corporation_ptsc bus_service.html }\end{array}$ \\
\hline \multicolumn{2}{|l|}{ EV1 Water Resources } \\
\hline All indicators & unstats.un.org/unsd/demographic/products/socind/default.htm \\
\hline \multicolumn{2}{|l|}{ EV2 Air Quality } \\
\hline Emissions of Greenhouse gases (difference 2000 to 2012) & edgar.jrc.ec.europa.eu/overview.php?v=GHGts1990-2012 \\
\hline \multicolumn{2}{|l|}{ EV3 Biodiversity } \\
\hline All indicators & www.biodiversity.gov.tt \\
\hline \multicolumn{2}{|l|}{ EV4 Renewable Energy } \\
\hline Energy consumption from renewables (\% of total) & data.worldbank.org/indicator/EG.FEC.RNEW.ZS \\
\hline \multicolumn{2}{|l|}{ EV5 Coastal and Marine Environments } \\
\hline All indicators & $\begin{array}{l}\text { www.ima.gov.tt/home/images/docs/Ingrated_Coastal_Zone_Mment_Policy_Fra } \\
\text { mework_Minister_April_2014.pdf }\end{array}$ \\
\hline \multicolumn{2}{|l|}{ EV6 Protected areas } \\
\hline Terrestrial and marine protected areas (\% of total territorial area) & $\begin{array}{l}\text { databank.worldbank.org/data/reports.aspx?source=world-development- } \\
\text { indicators\# }\end{array}$ \\
\hline \multicolumn{2}{|l|}{ EV7 Land Use } \\
\hline Urban footprint & www.un.org/esa/agenda21/natlinfo/countr/barbados/natur.htm \\
\hline Forests area & $\begin{array}{l}\text { databank.worldbank.org/data/reports.aspx?source=world-development- } \\
\text { indicators\# }\end{array}$ \\
\hline
\end{tabular}




\begin{tabular}{|c|c|}
\hline \multicolumn{2}{|l|}{ EV8 Ecotourism } \\
\hline $\begin{array}{l}\text { Measures of sectoral strength (see below): number of measures with high } \\
\text { level of strength. }\end{array}$ & $\begin{array}{l}\text { sustainabledevelopment.un.org/content/documents/1461Working\%20for\%20Sust } \\
\text { ainable\%20Development } \% 20 \text { in } \% 20 \text { Trinidad\%20and\%20Tobago.pdf }\end{array}$ \\
\hline \multicolumn{2}{|l|}{ EV9 Household \& Commercial Waste } \\
\hline All indicators & $\begin{array}{l}\text { sustainabledevelopment.un.org/content/documents/1461Working\%20for\%20Sust } \\
\text { ainable\%20Development\%20in\%20Trinidad\%20and\%20Tobago.pdf } \\
\text { www.swmcol.co.tt/education/112-waste-mgmt-topics.html }\end{array}$ \\
\hline \multicolumn{2}{|l|}{ EV9 Transport } \\
\hline Metric tons $\mathrm{CO} 2$ emissions from liquid fuels/ per capita & cdiac.ornl.gov/ftp/ndp030/nation.1751_2011.ems \\
\hline $\begin{array}{l}\% \text { Transport energy consumption (motor gasoline) as share in total crude oil } \\
\text { consumption (thousand barrels/d), }\end{array}$ & $\begin{array}{l}\text { knoema.com/UNSDESD2017/un-statistics-division-energy-statistics-database- } \\
\text { 1990-2014 }\end{array}$ \\
\hline $\begin{array}{l}\text { Transport } \mathrm{CO} 2 \text { emissions per capita (metric tons) (from consumption of } \\
\text { petroleum } \dagger \delta \text { ) }\end{array}$ & www.eia.gov/cfapps/ipdbproject/IEDIndex3.cfm?tid=5\&pid=5\&aid=8 \\
\hline \multicolumn{2}{|l|}{ CC1 Climate Change and Disaster Management } \\
\hline All indicators & $\begin{array}{l}\text { www.unisdr.org/partners/countries/ } \\
\text { Trinidad and Tobago DRR 2014, verified self-evaluation using UNISDR The } \\
\text { Identification of Disaster Risk Reduction Opportunities for the DIPECHO Action } \\
\text { Plan for the Caribbean 2015- } 2016\end{array}$ \\
\hline
\end{tabular}

